\title{
Size-class partitioning and herding in a foraging group of green turtles Chelonia mydas
}

\author{
Michael J. Bresette ${ }^{1, *}$, Blair E. Witherington ${ }^{2}$, Richard M. Herren ${ }^{1}$, Dean A. Bagley ${ }^{1}$, \\ Jonathan C. Gorham ${ }^{1}$, Steve L. Traxler ${ }^{1}$, Carrie K. Crady ${ }^{1}$, Robert Hardy ${ }^{3}$ \\ ${ }^{1}$ Inwater Research Group Inc., 4160 NE Hyline Dr., Jensen Beach, Florida 34957, USA \\ ${ }^{2}$ Florida Fish and Wildlife Research Institute, FWC, 9700 South A1A, Melbourne Beach, Florida 32951, USA \\ ${ }^{3}$ Florida Fish and Wildlife Research Institute, FWC, 100 Eighth Avenue SE, St. Petersburg, Florida 33701, USA
}

\begin{abstract}
To collect data on green turtles Chelonia mydas near the Marquesas Keys, Florida, USA, we conducted haphazard, unmarked, nonlinear transect (HUNT) surveys from a moving vessel. During HUNTs, we recorded green turtle locations and made opportunistic captures. We found a unique foraging assemblage of subadult and adult green turtles in open-water seagrass habitat ( 3 to $5 \mathrm{~m}$ deep) at the eastern Quicksands, west of the Marquesas Keys. At an adjacent area in the Marquesas Keys (Mooney Harbor), we observed juvenile green turtles foraging in shallow seagrass habitat $(<2 \mathrm{~m})$. During $267 \mathrm{~km}$ of HUNTs, 370 green turtles (153 adults, 216 subadults, 1 juvenile) were recorded from the eastern Quicksands. At the Mooney Harbor site, 190 juvenile green turtles were sighted during $309 \mathrm{~km}$ of transects. Green turtles captured at the eastern Quicksands were adult and subadult animals that ranged from 69.3 to $108.5 \mathrm{~cm}$ straight carapace length $\left(\mathrm{SCL}_{i}\right.$ mean $\pm \mathrm{SD}=$ $88.4 \pm 10.6 \mathrm{~cm}, \mathrm{n}=31$ ). Green turtles captured in Mooney Harbor were juveniles ranging from 27.0 to $59.3 \mathrm{~cm} \mathrm{SCL}$ (mean $=44.0 \pm 7.8, \mathrm{n}=41$ ). Six repeatable, linear transects were surveyed during 3 sampling events at the eastern Quicksands. During these transects, 238 green turtles were observed. These spatial data were used in a nearest-neighbor analysis, which indicated that the distribution of green turtles at the eastern Quicksands was non-random and clumped. We hypothesize that adult and large subadult green turtles use deeper water habitats than juveniles, and this size-class partitioning may be due to differing habitat requirements and predation risk. Our analyses indicate that green turtles found at the eastern Quicksands form foraging herds.
\end{abstract}

KEY WORDS: Green turtle $\cdot$ Foraging ground $\cdot$ Partitioning

\section{INTRODUCTION}

Green turtles Chelonia mydas are widely distributed, migratory marine turtles that nest on sandy beaches. Their hatchlings disperse from nesting beaches and occupy a pelagic and largely oceanic stage before recruiting to neritic waters (Bolten 2003). As neritic juveniles in coastal and estuarine habitats, green turtles feed principally on seagrasses and algae (Bjorndal 1985). In the western Atlantic, immature green turtles pass through multiple developmental habitats in the neritic zone before reaching adulthood (Bolten 2003).

Excluding hatchlings, most green turtles observed in southeastern US waters fit within 1 of 2 size classes: (1) juveniles, 20 to $65 \mathrm{~cm}$ straight carapace length (SCL), and (2) adults, generally $>90 \mathrm{~cm}$ SCL. Juvenile green turtles are known to forage within shallow bays, lagoons, and on nearshore reefs, and compose the most common life stage of this species found in the southeastern USA (Witherington et al. 2006). On Florida nesting beaches, adult females range from 83 to $114 \mathrm{~cm}$ in SCL (Witherington et al. 2006). For the purposes of general discussion in this paper, we arbitrarily used $90 \mathrm{~cm} \mathrm{SCL}$ as a minimum for adults in order to exclude large immature animals, and we arbitrarily used $65 \mathrm{~cm}$ SCL to separate size groupings of juveniles and subadults. At the St. Lucie power plant on Hutchinson Island, Florida, green turtles $<65 \mathrm{~cm}$ SCL 
composed $92 \%$ of 5384 in-water captures (authors' unpubl. data). Only $6 \%$ of green turtles at this site had SCLs of 65 to $90 \mathrm{~cm}$ and only $2 \%$ were $>90 \mathrm{~cm} \mathrm{SCL}$. Nearly all of the adult turtles were captured during the summer nesting season. Green turtles captured at inwater study sites throughout Florida have similar sizefrequency distributions with few reports of subadults, or of adults observed outside the summer nesting season (Bresette et al. 1998, 2000, Schmid 1998, Makowski et al. 2006, Ehrhart et al. 2007).

The gap in green turtle size-class distributions suggests that juvenile green turtles leave Florida waters as they approach $70 \mathrm{~cm}$ SCL. Ehrhart (1985) suggested that this shift provides ecological definitions separating younger juveniles and older subadult green turtles. A recent satellite tracking study of green turtles on the east coast of Florida confirms this developmental movement (D. Bagley unpubl. data).

Green turtles that nest in the southeastern USA are reproductively active from June to September, are not known to forage near their nesting beaches, and are assumed to leave the waters near these beaches immediately after their final clutch of the season. Although their foraging grounds are not known from empirical observations, green turtles have been satellite-tracked to the Florida Keys from nesting beaches in eastcentral Florida (B. Schroeder pers. comm.), the Florida Panhandle (M. Nicholas pers. comm.), and the Yucatan Peninsula (M. Garduno pers. comm.).

Between 2002 and 2007, we conducted surveys of sea turtles in the Key West National Wildlife Refuge (KWNWR) and the associated Marquesas Keys (Fig. 1) to describe relative abundance and species composition of sea turtles there. During this time, we recorded the presence of juvenile, subadult, and adult green turtles foraging on seagrass pastures near the Marquesas Keys. Here, we describe these green turtle assemblages and test 2 principal hypotheses: (1) green turtles of different sizes are partitioned by different foraging habitats, and (2) green turtles in the highest density aggregation have a non-random spatio-temporal distribution that may be a result of size-specific habitat requirements and response to predation risk.

\section{MATERIALS AND METHODS}

Study area. We observed and captured sea turtles in the waters between the Gulf of Mexico and the Atlantic Ocean, near the Marquesas Keys at the western extent of the KWNWR, Florida, USA (Fig. 1). The Marquesas Keys lie east of waters charted as the Quicksands and comprise 14 uninhabited mangrove islands that encircle an open, shallow basin known as Mooney Harbor. The center of Mooney Harbor is located $32 \mathrm{~km}$ due west of Key West, Florida. We focused on 2 principal areas of green turtle foraging habitat in the Marquesas region: Mooney Harbor $\left(24.567^{\circ} \mathrm{N}, 082.131^{\circ} \mathrm{W}\right)$ and an area west of the Marquesas Keys we will refer to as the eastern Quicksands $\left(24.563^{\circ} \mathrm{N}, 082.206^{\circ} \mathrm{W}\right)$. These waters lie within the Florida Keys National Marine Sanctuary.

Marine habitats in Mooney Harbor include shallow (mostly $<2 \mathrm{~m}$ ) seagrass beds consisting mainly of Thalassia testudinum interspersed with sponge and hard bottom. Sinusoidal channels (2 to $3 \mathrm{~m}$ deep) wind through shallow seagrass flats allowing tidal flow into and out of Mooney Harbor. Throughout Mooney Harbor are sand- and marl-bottomed depressions (1-3 m in depth and 20-350 $\mathrm{m}$ long $\times 20-60 \mathrm{~m}$ wide) within the shallow seagrass. At the lowest tides, shallow seagrass flats become exposed, isolating the depressions.

Green turtle foraging habitat at the eastern Quicksands consists of open-water seagrass pastures in depths of 3 to $5 \mathrm{~m}$. The center of our study area at the eastern Quicksands was approximately $5 \mathrm{~km}$ west of the Marquesas Keys (Fig. 1). The area experiences high tidal flow between the Gulf of Mexico to the north and the Atlantic Ocean to the south. The majority of the eastern Quicksands region contains seagrass pastures of Thalassia testudinum, Syringodium filiforme, and Halodule wrighti interrupted by drifts of Halimeda (coralline algal) sands up to $3 \mathrm{~km}$ long $\times 1 \mathrm{~km}$ wide. A

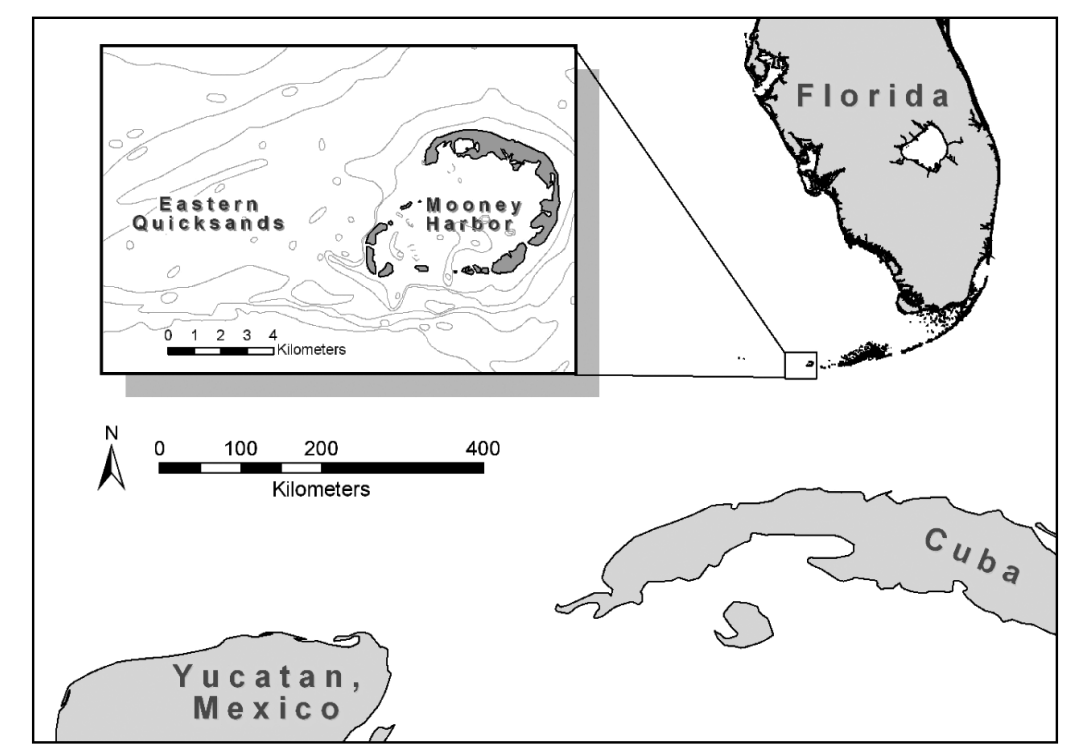

Fig. 1. Marquesas Keys study site, Florida, USA, including Mooney Harbor and eastern Quicksands 
small section of the southern region of the eastern Quicksands contains hard-bottom community species including sponges, octocorals, and stony corals interspersed with relatively small plots of $T$. testudinum. The eastern Quicksands does not encompass any reef formations with significant relief, and the only prominent hard structures are anthropogenic, viz. a few small wrecks and remnants of bombing target structures used by the US Navy in the mid-1900s.

Sea turtle observations and captures. We made vessel-based, visual observations of green turtles throughout the Marquesas Keys study area between July 2002 and October 2007. We conducted these surveys during $39 \mathrm{~d}$ at the Mooney Harbor site and $23 \mathrm{~d}$ at the eastern Quicksands. Surveys were conducted as part of our overall study of sea turtles in the KWNWR during 6 d sampling trips. The eastern Quicksands were not discovered until 2004, resulting in fewer sampling events. Our observations and effort were recorded using a method we describe as haphazard, unmarked, non-linear transects (HUNTs). In this method, 2 experienced observers stood atop a 2-m elevated central tower on a 7 -m long flat-bottomed skiff. During HUNTs, a helmsman recorded effort tracks and turtle locations with a Garmin Global Positioning System (GPS), and a data recorder made additional notes. The GPS recorded start and end locations of HUNTs as well as continuous vessel tracks ( $\sim 20 \mathrm{~m}$ resolution). Vessel speed during HUNTs was kept as close to $9 \mathrm{~km} \mathrm{~h}^{-1}$ as possible.

HUNTs were near haphazard with respect to course decisions made during transects and were biased by access opportunity. Access opportunity was influenced by water depths where our vessel could navigate and where subsurface turtles could be identified $(0.2$ to $6.0 \mathrm{~m}$ depth). Although HUNT locations were also biased by decisions made by the helmsman on each search episode, efforts were made not to overlap with previous vessel paths within each day of transects. Lengths of HUNTs in distance or time were not predetermined and ended either with a sea turtle capture or a move to another location.

Green turtles sighted during HUNTs were identified to life stage (size estimate: juvenile $<65 \mathrm{~cm} \mathrm{SCL;}$ subadult 65-90 cm SCL; adult $>90 \mathrm{~cm} \mathrm{SCL}$, and; undetermined). To calculate observer error rate in life-stage determinations, we compared initial sighting determinations to actual measurements of the same turtle. Sea turtle sightings $\mathrm{km}^{-1}$ of transect effort were calculated by dividing the number of turtles sighted by vessel track length.

In addition to the HUNT method, we recorded green turtle observations and search effort made along linear, repeatable transects at the eastern Quicksands site approximately 2 to $8 \mathrm{~km}$ west of the Marquesas
Keys on 3 occasions: 19 July 2006, 8 January 2007, and 17 October 2007. As in the HUNT method, transects were conducted with 2 experienced observers in an elevated tower, a helmsman, and a data recorder.

We conducted these transects along 6 predetermined lines oriented east-west, each $6 \mathrm{~km}$ long and separated by $1 \mathrm{~km}$ from adjacent lines. The lines lay on a $6 \times 6 \mathrm{~km}$ square covering an area of patchy seagrass where we had observed numerous green turtles during previous HUNTs. Green turtles sighted during these transect surveys were identified to life stage, and their locations relative to the transect line were recorded on a GPS unit.

In conjunction with HUNTs, turtles at each study site were captured using the rodeo method (Ehrhart \& Ogren 1999). Measurements were made using an aluminum forestry caliper and a graduated fiberglass tape as described by Pritchard et al. (1983). We used tail length to determine sex in turtles $>90 \mathrm{~cm}$. In a study that included direct laparoscopic examination of gonads, Meylan et al. (1994) found that absolute tail length was a good predictor of maturity in male green turtles. Tail measurements were taken with a flexible tape from the base of the plastron (posterior anal scute) to the tip of the tail. Inconel tags (National Band and Tag No. 681) were applied to the trailing edge of each front flipper, and a passive integrated transponder (PIT) tag was applied subcutaneously to the right front flipper.

Prior to release, we painted numbers on each turtle's carapace with white polyester resin mixed with hardener catalyst. These markings allowed us to subsequently identify an observed turtle within multi-day sampling episodes without having to re-capture it. Resightings of turtles after $24 \mathrm{~h}$ were treated as separate independent observations.

Analyses. We imported sea turtle locations recorded with GPS into ESRI's ArcGIS 9.3 for analysis and mapping. Within transects, sighting frequency was calculated as the number of turtle sightings $\mathrm{km}^{-1}$. We grouped sightings from the linear repeated transects at the eastern Quicksands into 25 and 50\% minimum convex polygons for comparisons between survey dates. From these mapped data, we measured the distance between distribution centers (means) for each survey date. In addition, we used observations made during these repeated linear transects for a nearestneighbor analysis of spatial distribution (Clark \& Evans 1954, Pinder \& Witherick 1975). In this analysis, we measured distances between each observed turtle and its nearest neighbor along the transect line. From means of nearest-neighbor distances, we modeled a Poisson distribution that could be tested for goodness of fit to the actual distribution of nearest-neighbor distances. Our goal was to test competing hypotheses of 
random or clumped spatial distributions. SCL means for green turtles at the 2 study sites were compared using a 2-tailed $t$-test.

\section{RESULTS}

\section{Observations during HUNTs}

We made 560 observations of green turtles over $575.9 \mathrm{~km}$ of HUNTs between July 2002 and October 2007. We observed 370 green turtles on $266.7 \mathrm{~km}$ of transects at the eastern Quicksands and 190 green turtles on $309.2 \mathrm{~km}$ of transects in Mooney Harbor (Table 1, Figs. $2 \& 3$ ).

Sighting frequency of green turtles at the eastern Quicksands was 1.39 turtles $\mathrm{km}^{-1}$ of transect. Sighting frequencies were highest for adult-size and subadult-

Table 1. Chelonia mydas. Haphazard, unmarked, non-linear transect (HUNT) sightings $\mathrm{km}^{-1}$ of transect at eastern Quicksands $(266.7 \mathrm{~km})$ and Mooney Harbor $(309.2 \mathrm{~km})$ in the Marquesas Keys, Florida, USA, 2002 to 2007

\begin{tabular}{|lcc|}
\hline Lifestage & Eastern Quicksands & Mooney Harbor \\
\hline Juvenile & $0.004(\mathrm{n}=1)$ & $0.61(\mathrm{n}=190)$ \\
Subadult & $0.81(\mathrm{n}=216)$ & $0.00(\mathrm{n}=0)$ \\
Adult & $0.57(\mathrm{n}=153)$ & $0.00(\mathrm{n}=0)$ \\
\hline
\end{tabular}

size turtles, with only 1 juvenile observed (Table 1). From 27 green turtles at the eastern Quicksands that were assigned initial size estimates and were later captured, we found that $74 \%$ of initial size-class assignments matched those made from measurements following capture. Of 7 turtles initially assigned an incorrect size class, 4 were adults initially identified as subadults and 3 were subadults initially called adults.

Green turtles sighted using the HUNT method in Mooney Harbor were juvenile-size animals $(<65 \mathrm{~cm}$ SCL). No adult- or subadult-size green turtles were sighted in Mooney Harbor (Table 1). At this site, 95\% of initial size-class assignments matched those made using measurements. Of 37 green turtles assigned size estimates at initial observation and later captured, we verified 35 correct initial observations after measurements were taken. The 2 incorrect size designations were both juvenile green turtles that were initially identified as subadults.

\section{Repeated-transect observations and nearest- neighbor analyses}

The linear, repeated transects conducted within the $6 \times 6 \mathrm{~km}$ area at the eastern Quicksands totaled $108.5 \mathrm{~km}$ for the three $1 \mathrm{~d}$ transect efforts performed in July 2006 (35.91 km), January 2007 (35.94 km), and October 2007 (36.60 km). During these transects, we

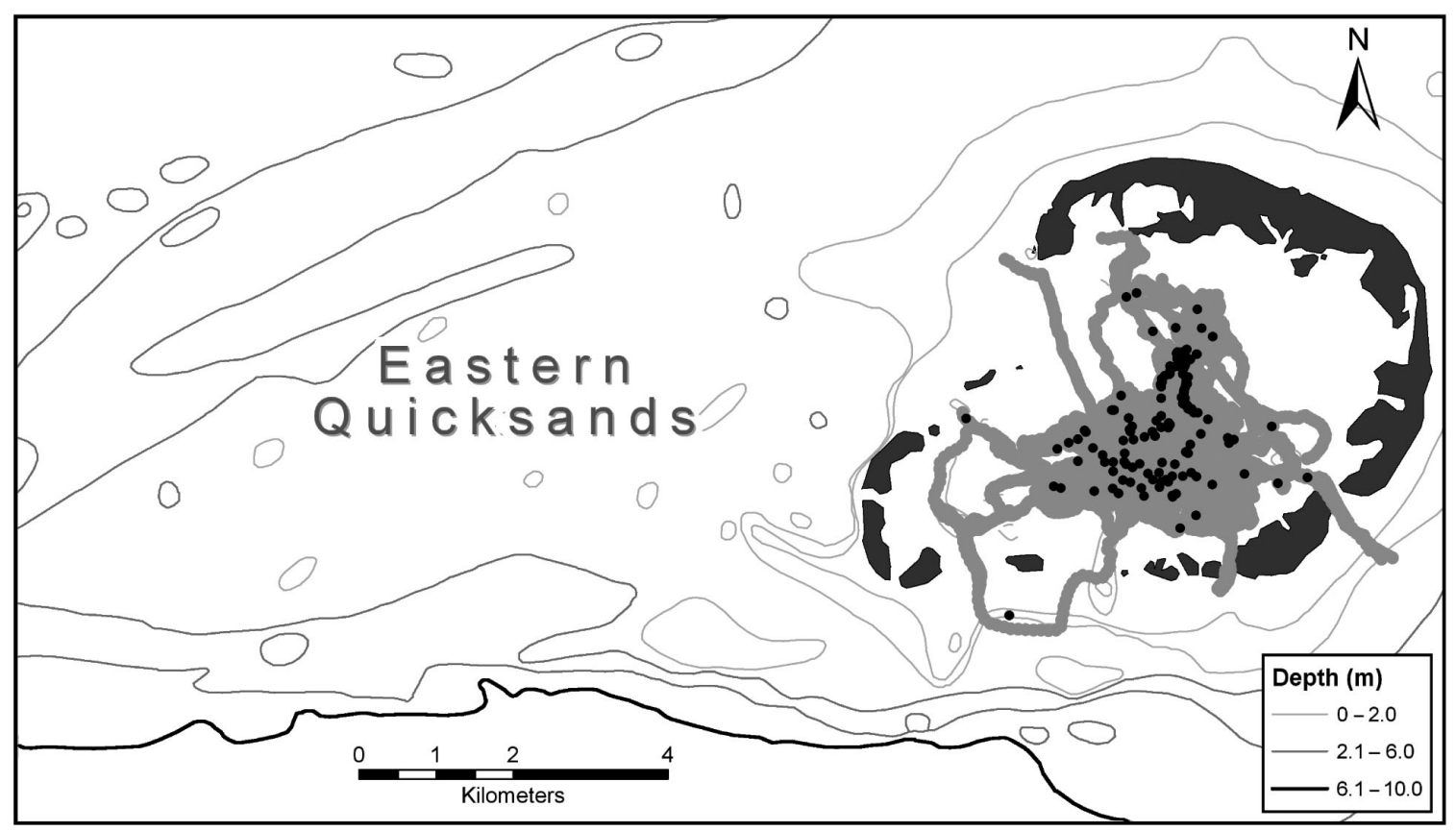

Fig. 2. Chelonia mydas. Haphazard, unmarked, non-linear transects (HUNTs) and green turtle observations at Mooney Harbor, Marquesas Keys, Florida, USA, July 2002 to October 2007. Figure represents 190 juvenile-size green turtle observations (black dots) during $309.2 \mathrm{~km}$ of transects (grey shading) 


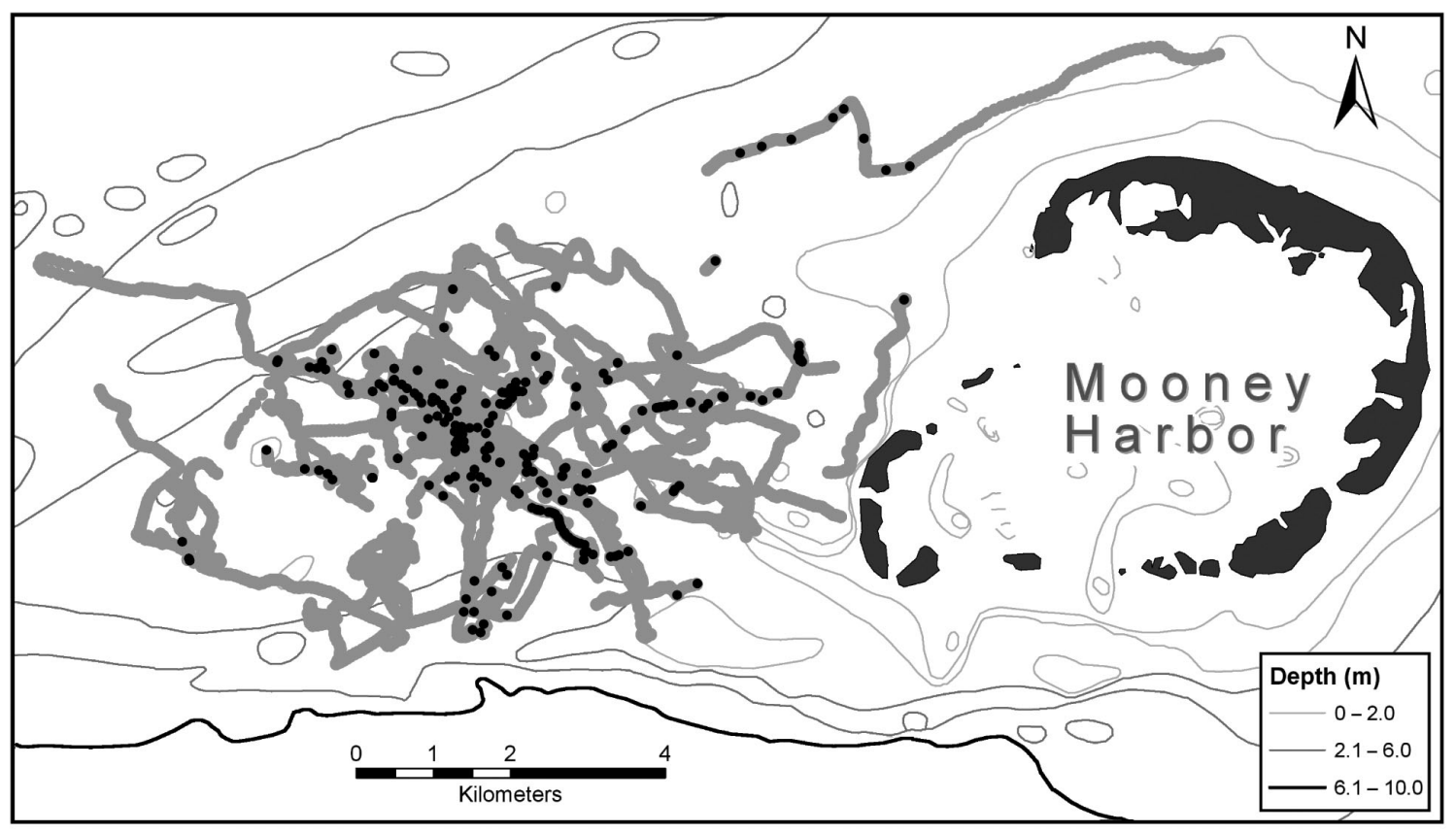

Fig. 3. Chelonia mydas. Haphazard, unmarked, non-linear transects (HUNTS) and green turtle observations at eastern Quicksands, Marquesas Keys, Florida, USA, July 2002 to October 2007. Figure represents 153 adult-size, 216 subadult-size, and 1 juvenile-size green turtle observations (black dots) during $266.7 \mathrm{~km}$ of transects (grey shading)

observed 238 green turtles with estimated sizes corresponding to 134 adult-size turtles, 99 subadult-size turtles, 1 juvenile-size turtle, and 4 green turtles estimated to be either subadult or adult animals. Sighting frequency of all green turtles observed during these transects was 2.19 turtles $\mathrm{km}^{-1}$ of transect. Respective sighting frequencies of adult-size, subadult-size, and juvenile-size turtles were 1.24, 0.91, and 0.01 turtles $\mathrm{km}^{-1}$ of transect.

We measured nearest-neighbor distances for 237 green turtles observed along the transects within the $6 \times 6 \mathrm{~km}$ area at the eastern Quicksands. Nearly half $(46 \%)$ of these observed turtles were within $100 \mathrm{~m}$ of their nearest neighbor. On each of the 3 linear-transect survey dates (Figs. 4 to 6), the distribution of nearestneighbor distances was significantly different from the Poisson distribution modeled using mean nearestneighbor distances (chi-squared goodness of fit, bins $<5$ observations collapsed, $\mathrm{df}=5,3$, and 4 , respectively, for the 3 dates, for each date $p<0.0001$ ). Median nearest-neighbor distances for July 2006, January 2007, and October 2007 were 49, 126, and $29 \mathrm{~m}$, respectively. Calculated indices of aggregation ( $R$, ratios of observed to expected mean distances) were less than 1 on each date, indicating clumped spatial distributions (Krebs 1989). In keeping with clumped distributions, nearest-neighbor distances on each date were skewed shorter than the distribution expected from random spatial occurrence (Figs. 4 to 6), and this clumping is seen in the mapped sighting data from the linear, repeated transects (Fig. 7). To test the hypothesis that green turtles were clumped in similar areas of the $6 \times 6 \mathrm{~km}$ area between sampling dates, we compared the spatial distribution of green turtles using mean centers and minimum convex polygons that included 25 and $50 \%$ of sightings (Fig. 8). Mean centers were separated by approximately $1 \mathrm{~km}$, and there was no overlap of the $25 \%$ polygons (Fig. 8).

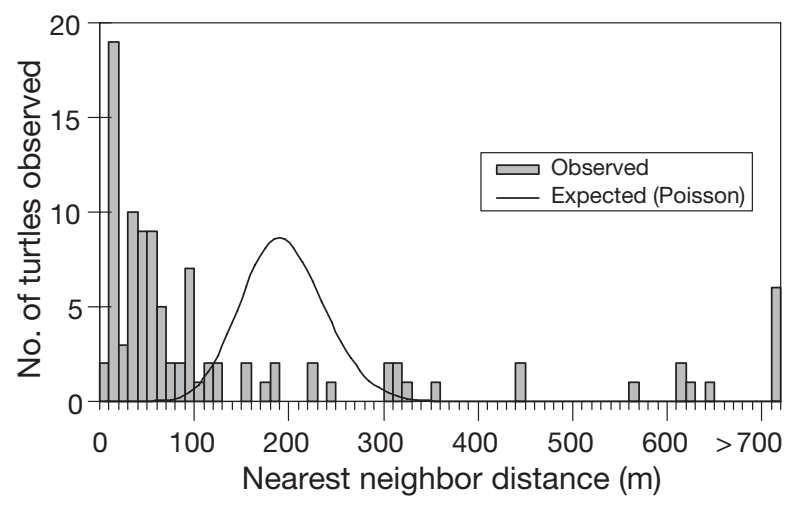

Fig. 4. Chelonia mydas. Nearest-neighbor distances of 100 green turtles observed on linear transect surveys $(35.91 \mathrm{~km}$ distance) at the eastern Quicksands, west of the Marquesas Keys, Florida, USA, on 19 July 2006. The line represents an expected distribution of nearest-neighbor distances based on a Poisson model. The Poisson model was derived from the mean observed nearest-neighbor distance of $192 \mathrm{~m}$ 


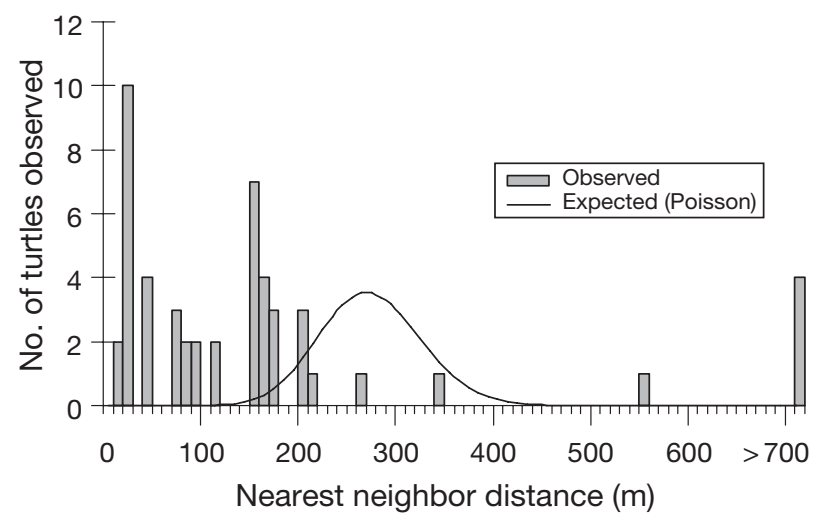

Fig. 5. Chelonia mydas. Nearest-neighbor distances of 50 green turtles observed on linear transect surveys $(35.94 \mathrm{~km}$ distance) at the eastern Quicksands, west of the Marquesas Keys, Florida, USA, on 8 January 2007. The line represents an expected distribution of nearest-neighbor distances based on a Poisson model. The Poisson model was derived from the mean observed nearest-neighbor distance of $266 \mathrm{~m}$

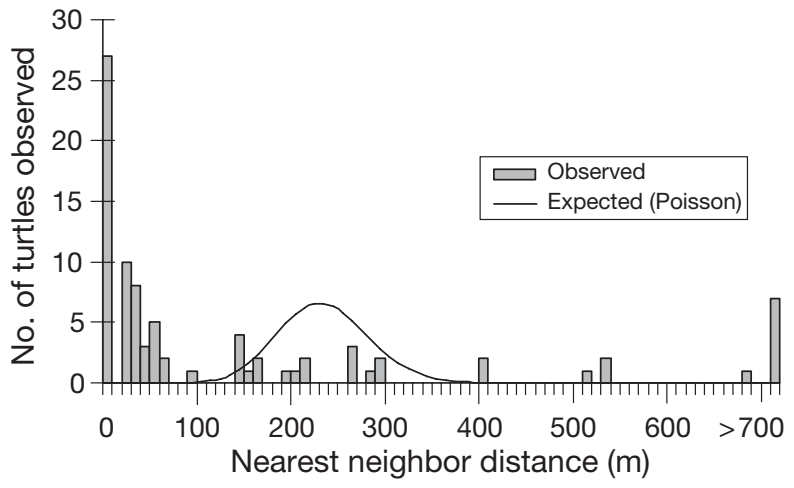

Fig. 6. Chelonia mydas. Nearest-neighbor distances of 87 green turtles observed on linear transect surveys $(36.60 \mathrm{~km}$ distance) at the eastern Quicksands, west of the Marquesas Keys, Florida, USA, on 17 October 2007. The line represents an expected distribution of nearest-neighbor distances based on a Poisson model. The Poisson model was derived from the mean observed nearest-neighbor distance of $227 \mathrm{~m}$

\section{Size frequencies}

During the present study, 31 green turtles were captured at the eastern Quicksands site, and 41 at the Mooney Harbor site. Green turtles at the eastern Quicksands ranged in size from 69.3 to $108.5 \mathrm{~cm}$ SCL with a mean $\pm \mathrm{SD}$ of $88.4 \pm 10.6 \mathrm{~cm}$ (Fig. 9). Fifteen adult-size and 16 subadult-size green turtles were captured at the eastern Quicksands site including 10 likely females (adult-size with short tails), 5 likely males (adult-size with long tails), 2 likely maturing males (nearly adult-size with medium-long tails), and 14 subadults not differentiated by secondary sexual characteristics. Green turtles captured at the Mooney Harbor site were all juveniles $27.0 \mathrm{~cm}$ to $59.3 \mathrm{~cm}$ SCL with a mean of $44.0 \pm 7.8 \mathrm{~cm}$ (Fig. 9). A $t$-test revealed that the
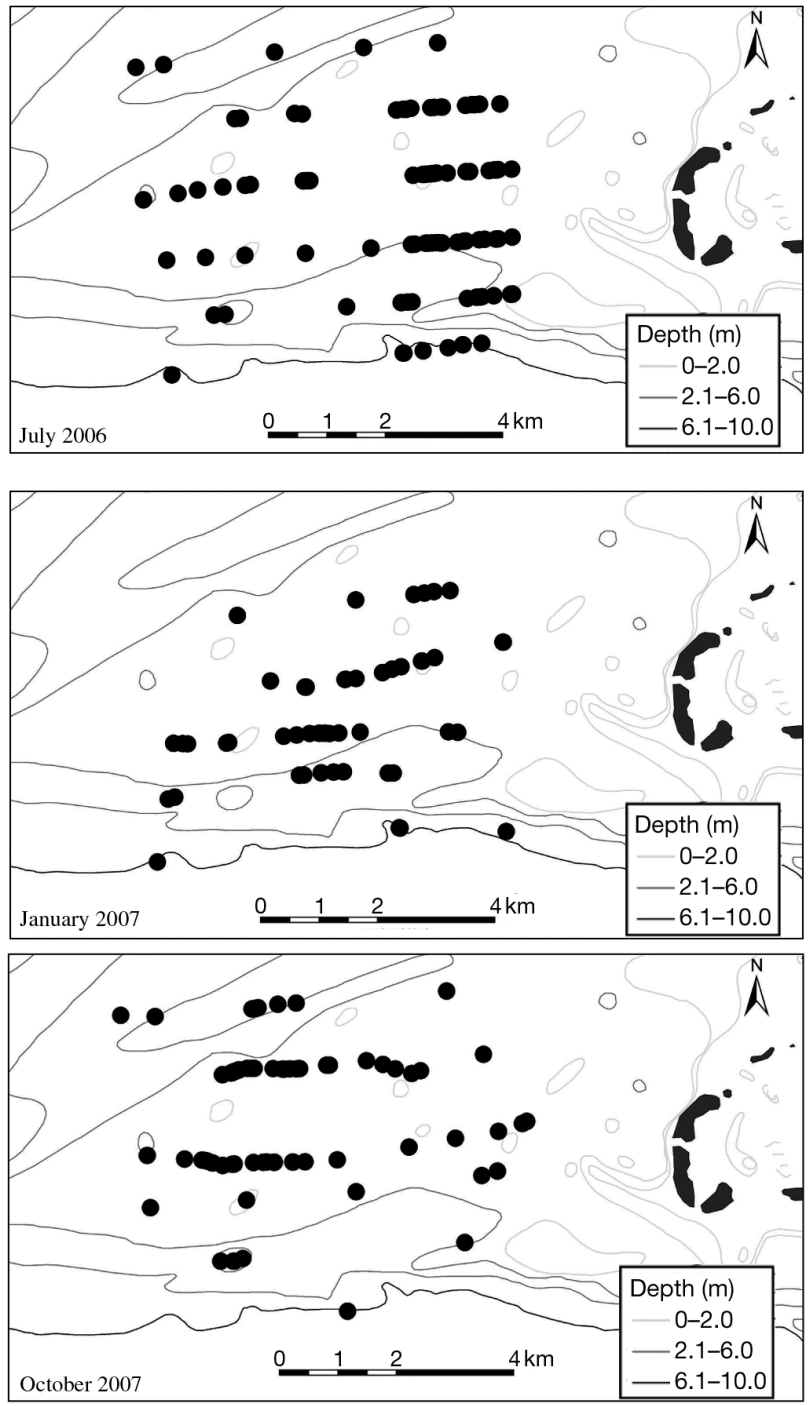

Fig. 7. Chelonia mydas. Adult-size and subadult-size green turtle observations at eastern Quicksands (black dots), west of the Marquesas Keys, Florida, USA, during linear, repeated transects on 19 July $2006(\mathrm{n}=100), 8$ January $2007(\mathrm{n}=50)$, and 17 October $2007(\mathrm{n}=87)$

mean SCL of green turtles captured at the eastern Quicksands was significantly greater than that of green turtles captured at the Mooney Harbor study site $(\mathrm{p}<$ 0.05 , df $=53$ ). This was not surprising given that there was no overlap in size ranges for captured turtles between the 2 sites (Fig. 9).

\section{DISCUSSION}

\section{Green turtle partitioning by size and habitat}

Green turtles foraging in the Marquesas Keys region were partitioned by size. The 2 assemblages of green turtles that we studied had little or no overlap 


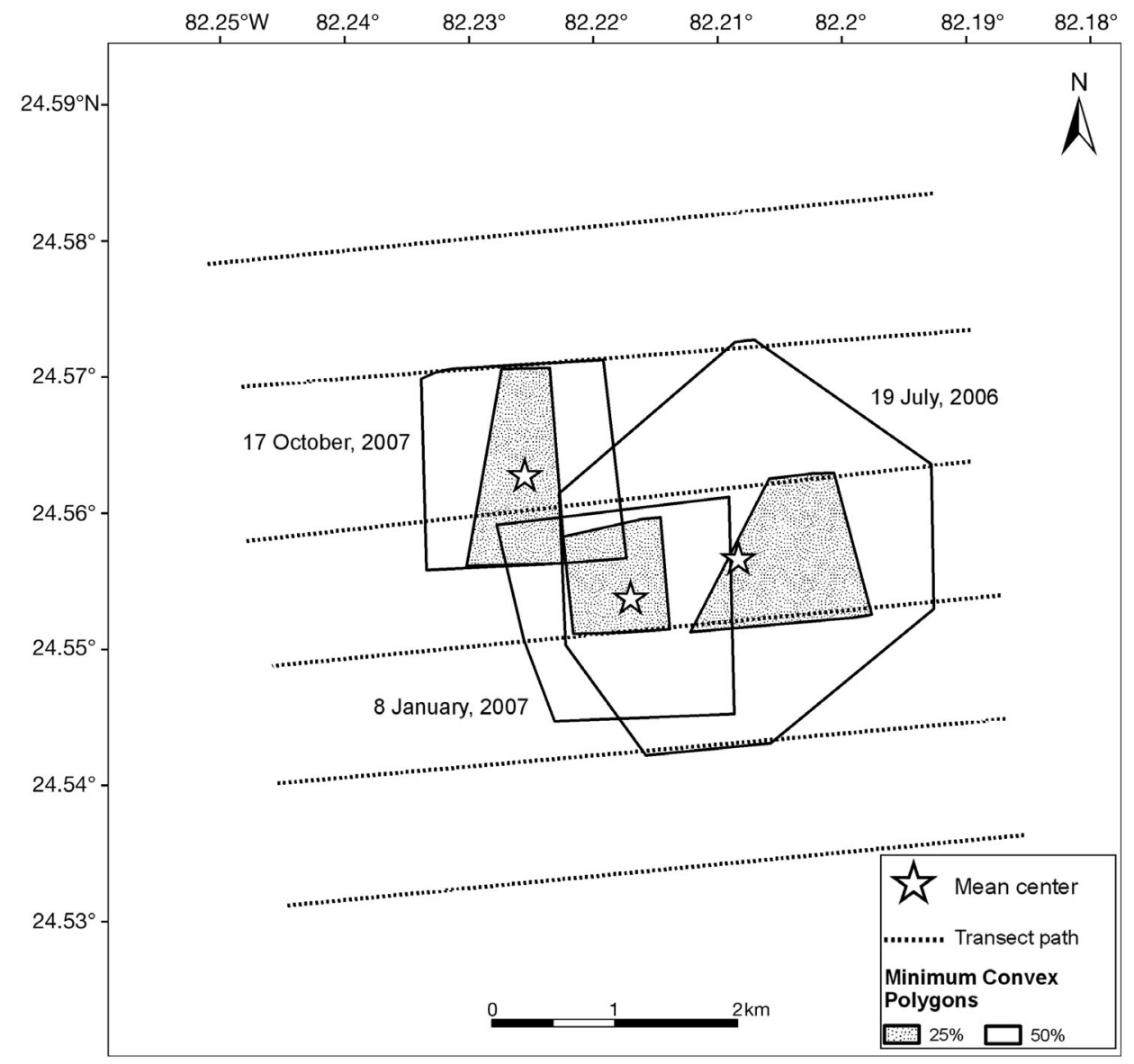

Fig. 8. Chelonia mydas. Minimum convex polygons including 25 and $50 \%$ of all green turtle sightings with mean center distribution points during linear, repeated transects conducted on 19 July 2006, 8 January 2007, and 17 October 2007 at the eastern Quicksands, Marquesas Keys, Florida, USA

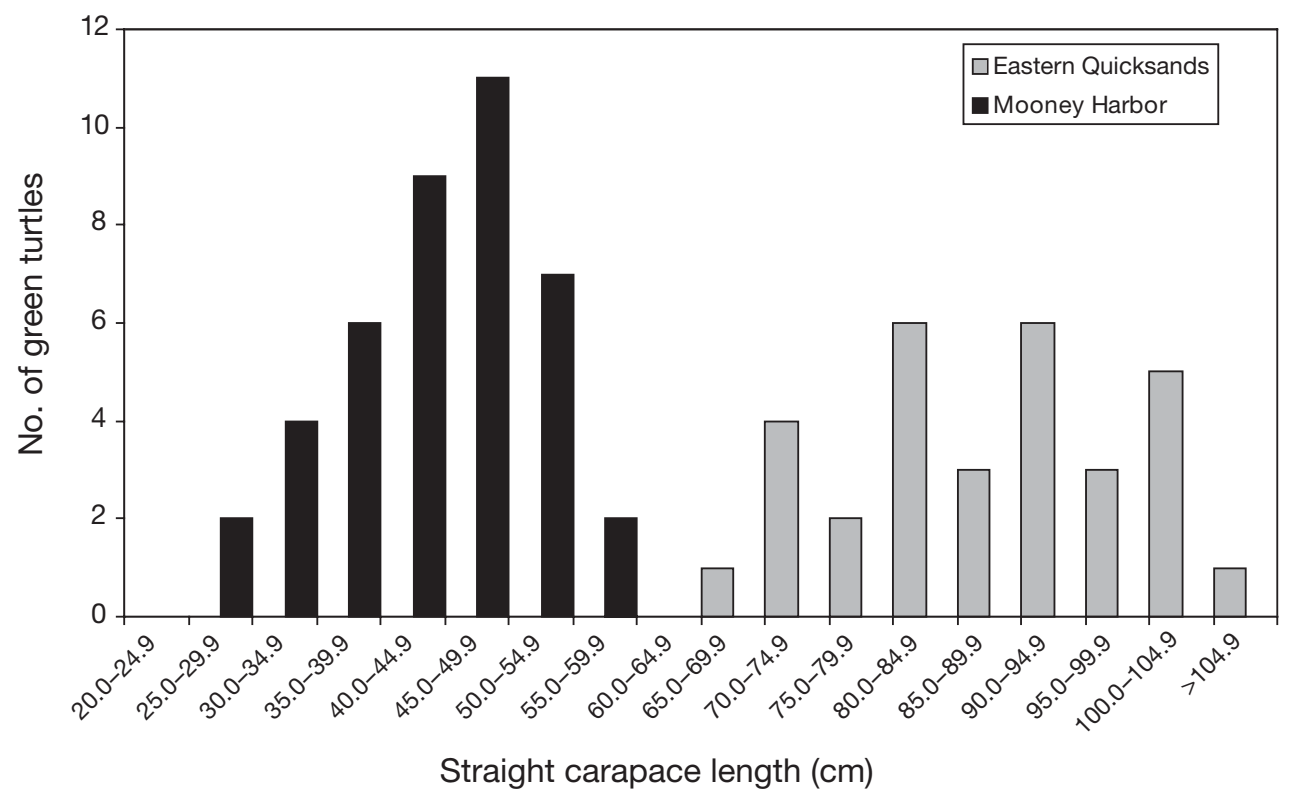

Fig. 9. Chelonia mydas. Size frequencies of green turtles captured at the eastern Quicksands (n = 31) and Mooney Harbor $(\mathrm{n}=41)$, Marquesas Keys, Florida, USA (2002 to 2007) 
in size structure, yet they were separated by only 3 to $5 \mathrm{~km}$. Habitats occupied by the 2 assemblages were distinct but had only slight differences in bathymetry. We found juvenile-size green turtles predominantly on shallow $(<2 \mathrm{~m})$ seagrass pastures in Mooney Harbor, and subadult and adult size turtles predominately on seagrass beds in the deeper waters (3 to $5 \mathrm{~m}$ ) of the eastern Quicksands. Although juvenile green turtles within Mooney Harbor had a size distribution similar to foraging assemblages found throughout the southeastern USA, the subadult and adult-size green turtles at the eastern Quicksands were sizes not commonly found in this geographic range. The eastern Quicksands has the only foraging assemblage of adult-sized green turtles reported from southeastern US waters.

Size-class partitioning of green turtles between adjacent habitats has rarely been reported, which may indicate that size-dependent habitat needs often necessitate wide geographic separation. These differing habitat requirements are believed to bring about extensive developmental migrations in green turtles (Meylan et al. 2000, Bjorndal et al. 2003). As an example, juvenile green turtles from the shallow Indian River Lagoon system of Florida's Atlantic coast have been tagged and recovered as subadult- or adult-size turtles at foraging grounds in the northern and western Caribbean (Moncada et al. 2006, Ehrhart et al. 2007, L. Ehrhart unpubl. data). Size-distribution differences between juvenile green turtles from shallow Florida lagoons (Ehrhart et al. 2007) and subadult/ adult green turtles from deeper seagrass pastures off Nicaragua ( 2000 km apart; Campbell \& Lagueux 2005) are similar to differences we observed in green turtles from habitats in the Marquesas Keys region that were only separated by a few kilometers.

Similar size distribution differences between east Pacific green turtles (black turtles) in the coastal waters of Baja California Sur, Mexico, appear to be related to habitat differences and water depth. There, Koch et al. (2007) noted size differences between green turtles captured on the Pacific coast at Bahia Magdelena and those captured at study sites in the Gulf of California (Seminoff et al. 2003). Green turtles captured at Bahia Magdelena were mostly juveniles found in shallow coastal lagoons, whereas turtles captured at sites in the Gulf of California ( 800 km away) were mostly large juveniles and adults from deeper water. The only definitive report of size-class partitioning between adjacent habitats we found came from Shark Bay, Australia. There, Heithaus et al. (2005) found that large green turtles were most often captured in moderately deep water (3.0-5.0 m), whereas juveniles were more likely to be found in shallower water $(0.5-1.5 \mathrm{~m})$, near the shore, and in areas lined with mangroves. This description is similar to our observations in the Marquesas Keys.

We hypothesize that green turtle size partitioning between habitats is a result of size-specific habitat requirements and predation risk. The juvenile turtles in this study are likely to be more vulnerable to predation by sharks than larger subadult and adult turtles. The shallow water habitat within Mooney Harbor likely reduces the risk of predation by limiting access to large sharks. Heithaus et al. (2005) hypothesized that shallow water habitats in Shark Bay provided juvenile green turtles with refuge from predation by tiger sharks Galeocerdo cuvier. This same species is found in the waters surrounding the Marquesas Keys and is known to specialize in feeding on sea turtles (Witzell 1987). This is not a unique predator avoidance mechanism in the marine environment, as many fish species utilize shallow water habitat to minimize predation risk (Linehan et al. 2001). For example, in a study of lemon shark Negaprion brevirostris habitat preference, Morrissey \& Gruber (1993) found that juvenile lemon sharks selected shallow, warm-water habitats as a hypothesized tactic to avoid predation by larger sharks. Juvenile green turtles in Mooney Harbor may receive a similar benefit from foraging in shallow water where large sharks risk exposure and have difficulty maneuvering.

At low tide in Mooney Harbor, much of the shallow seagrass pastures become partially exposed leaving only a few basins and channels with water depths of more than $1 \mathrm{~m}$. However, within the expanses of these shallow seagrass flats there are several sand-bottomed depressions, 2 to $3 \mathrm{~m}$ deep, which are surrounded by exposed seagrass beds during the lowest tides. On an ebbing tide we have observed green turtles actively seeking out these areas to avoid being stranded on the exposed flats. We have recorded high densities of green turtles in these areas, with as many as 30 turtles observed within a single 2.1 ha depression. Sightings of juvenile green turtles pushing wakes through water roughly equal to their own body depth to reach these depressions is not uncommon in Mooney Harbor.

Because these depressions are mostly bare with little recognizable forage, we hypothesize that they are occupied principally as a refuge from tidal exposure and predation. At low tide, these sandy holes would be inaccessible to large sharks and would serve as refuges for several hours during the day. We reason that at low tide, the depressions and the shallows surrounding them do not provide adequate habitat for large sharks. These predators would suffer more severe consequences from accidental exposure if they failed to reach the depression and might have difficulty surviving high water temperatures (during summer) and low dissolved oxygen levels within these iso- 
lated areas. During high tide, juvenile green turtles forage throughout Mooney harbor in water depths as deep as $2 \mathrm{~m}$, but are in close proximity to the relative safety of surrounding flats that are less than $0.5 \mathrm{~m}$ deep.

Numerous juvenile green turtles utilize the isolated depressions in Mooney Harbor, but we have recorded very few green turtles in the nearby open-ended channels of similar depth. Because we have several observations of large sharks in these channels, we propose that juvenile green turtles limit their use to reduce predation risk. The channels that exit Mooney Harbor lead to deeper, open waters surrounding the Marquesas Keys where there are extensive seagrass beds but few reefs or tidal flats where juvenile turtles could seek refuge from predators. In September 2002, we observed a tiger shark approximately $3 \mathrm{~m}$ in length feeding on the fresh carcass of a subadult green turtle just offshore of the Marquesas Keys.

In a preliminary examination of diet items from esophageal lavage, we found that green turtles at both study sites fed mainly on seagrass species. Juvenile green turtles in Mooney Harbor fed most commonly on Thalassia testudinum and Halodule wrightii and green turtles at the eastern Quicksands fed mainly on Syringodium filiforme and $H$. wrightii (authors' unpubl. data). Other evidence from the eastern Quicksands suggests that green turtles are important grazers at this site, as we have observed numerous closely cropped grazing plots similar to those described by Bjorndal (1980) and floating green turtle feces throughout the study area.

\section{Evidence for herding}

Our analysis of nearest-neighbor distances revealed that green turtles foraging on the seagrass pastures of the eastern Quicksands were not randomly distributed (Figs. 4 to 6) and had a clumped distribution for each of 3 sampling episodes. Because the spatial distributions between sampling periods had different geographic centers (Fig. 8), we propose that the clumped distributions were a result of turtles grouping with each other rather than within clumped habitat patches. We do not have adequate spatial descriptions of the seagrass habitat at the site, but the seagrass was easily visible and we did not notice any large changes in seagrass coverage between the 3 sampling episodes, which took place within a relatively short period (15 mo). Although our nearest-neighbor distance measurements included both surface $(46 \%)$ and below-water (54\%) observations of turtles, it is likely that many turtles below the surface went unobserved. Because of this, we believe that our median nearest-neighbor dis- tances are underestimates. Under ideal sighting conditions, we observed numerous instances of 2 to 6 adult and subadult green turtles foraging within 1 to $3 \mathrm{~m}$ of each other and in visual proximity to other groups of foraging turtles. During each sampling episode, the turtle groups we observed were mainly over seagrass, yet there were vast areas of seagrass in similar water depths that lacked turtles or evidence of grazing plots. Because even large subsurface animals are difficult to see, we believe the groups we observed were larger than we could record.

We propose that the green turtles at the eastern Quicksands site move in foraging herds. Although herding in large herbivorous vertebrates has been commonly observed and widely studied, we believe that this is the first evidence of herding in an assemblage of foraging sea turtles. Benefits of herding for foraging green turtles are likely to be similar to those reasoned for and demonstrated in other large herbivores (Hamilton 1971). One straightforward benefit to herd members is dilution of predation risk (Morton et al. 1994), but additional survival benefits may come from enhanced group vigilance for predators. Herd vigilance may be more important for the subadult and adult green turtles in the present study because habitat at the eastern Quicksands has no significant reef structure that would provide refuge from predators.

As individuals, large green turtles are strong swimmers protected by a tough carapace and are larger than the mouths of most sharks. Nonetheless, large sharks are clearly able to remove limbs and occasionally kill large sea turtles (Witzell 1987). Avoiding this predation may hinge on avoiding surprise attacks. As in other large animals threatened by predators, green turtles may take part in anti-predator behaviors brought about both by direct detection of predators and by the startle responses of fellow herd members. Due to behavioral time-budget considerations, predator vigilance that is subsidized by other herd members is likely to result in additional foraging opportunities. Kildaw (1995) reported that the largest groups of black-tailed prairie dogs Cynomys budovicianus spent the least time scanning for predators and devoted the most time to feeding. Kildaw (1995) also found that prairie dogs in large groups tended to forage in riskier locations than individuals in small groups. We believe the eastern Quicksands is a risky foraging location for green turtles, but by forming herds, green turtles mitigate predation risk while benefiting from increased foraging opportunities.

Green turtles within a herd may also benefit from increased foraging success brought about by the foraging actions of other herd members. In this respect, green turtles may differ markedly from terrestrial grazers in the effects that each has on its source of forage. 
Whereas most terrestrial grazers such as ungulates tread on their forage and deliver effects beyond removing the vegetation they eat, green turtles glide over their forage and, except for feeding, have only minor contact with the seagrass. In feeding, green turtles are adept at cropping seagrass blades without significant damage to the remaining plant (Bjorndal 1980). New growth from cropped seagrasses has been shown to be higher in nutrition and easier to digest than older, uncropped seagrass blades (Bjorndal 1985, Moran \& Bjorndal 2007). This nutritional benefit is believed to favor green turtles that maintain and selectively feed within grazing plots (Bjorndal 1985). At the eastern Quicksands site, we commonly observed groups of green turtles within well defined grazing plots. We hypothesize that these green turtles benefit not only from their own grazing maintenance, but also from the grazing maintenance of others in their herd. A similar foraging benefit to individuals in a group was seen for flocks of brent geese Branta bernicla feeding on the new growth of sea plantain Plantago maritima (Prins et al. 1980).

Adult green turtle foraging grounds in the western Atlantic have been identified through tracking females from nesting beaches using satellite telemetry, yet few data exist detailing relative abundance, size-class frequency, and habitat usage at these sites. This is likely due to the difficulty of conducting inwater studies in remote, open water habitats. For example, off the Caribbean coast of Nicaragua where an important foraging ground exists, data are gathered from green turtles brought in by local sea turtle fishermen (Campbell \& Lagueux 2005). However, the harvest of adult and subadult green turtles at this site is typically conducted at nocturnal resting areas (sleeping rocks), and the foraging grounds remain unknown (C. Lagueux pers. comm.). Foraging grounds off the coasts of Honduras, Nicaragua, Costa Rica, Panama, and Cuba have also been identified through satellite tracking and tag returns of green turtles from the largest rookery in the Atlantic at Tortuguero, Costa Rica (Troëng et al. 2005). To our knowledge, there are no published accounts describing the foraging behavior of green turtles at these sites, so future research effort could reveal that the herding behavior we observed is not unique to the eastern Quicksands foraging ground.

The only reference we did find of green turtles forming foraging groups comes from the Western Indian Ocean at Mayotte Island. There, Roos et al. (2005) reported that large green turtles ( $86 \%$ were adult-size) observed during snorkeling surveys in water $<5 \mathrm{~m}$ were 'generally found in small groups of 4 or 5 individuals.' This is similar to our observations off the Marquesas Keys.

\section{Reproductive movements}

Florida beaches may be an important destination for nesting females from the eastern Quicksands foraging area, given that 10 of 11 green turtles tracked from Florida's central Atlantic beaches migrated to and established residency in foraging areas in the Florida Keys (B. Schroeder pers. comm.). Evidence from the eastern Quicksands site indicates that this area may be an important foraging ground for rookeries in the Caribbean Basin as well. Of the 10 adult-sized green turtles captured at this site that were presumed to be mature females, 2 were later found nesting on the beaches of Quintana Roo, Mexico. The first, captured at the eastern Quicksands in June 2006, was later found nesting in July 2007. The second turtle was tagged in July 2006 and was found nesting in July 2008. A third green turtle captured at the eastern Quicksands in September 2008 had originally been tagged while nesting at Tortuguero, Costa Rica, in August 2005 (E. Harrison pers. comm.). From these recaptures it is evident that the green turtle aggregation at the eastern Quicksands is composed of adult turtles from multiple western Atlantic rookeries. Green turtles from these rookeries may benefit from having a foraging area without an artisanal or commercial green turtle fishery.

\section{CONCLUSIONS}

Green turtles forage on seagrass pastures near the Marquesas Keys and are partitioned by size between shallow ( $2 \mathrm{~m}$ ) and slightly deeper ( 3 to $5 \mathrm{~m}$ ) water habitat. There was little or no overlap in size structure of green turtles in these adjacent habitats, indicating that there was a strong effect of size on where turtles choose to forage. Size-specific effects may include limited access to shallow habitats by large turtles and increased predation risk of small turtles in deeper, open waters. We propose that larger green turtles foraging in open waters reduce predation risk by foraging in herds. We observed clumped spatial distributions in green turtles at the eastern Quicksands that showed different spatial centers between sampling episodes, evidence that is consistent with herding. The foraging herds at the eastern Quicksands include adult turtles that take part in reproductive migrations to Florida's Atlantic coast, the Yucatan Peninsula, and Costa Rica, and also include subadults, which are virtually unknown from the remainder of the green turtle's range in the southeast USA. Because of the importance of the Quicksands region to foraging green turtles, we recommend that this area be given status within the Florida Keys National Marine Sanctuary as a 'Sanctuary Preservation Area.' 
Acknowledgements. T. Wilmers provided support in attaining the initial funding for this project. We gratefully acknowledge the following organizations and people who provided the funding, equipment, and other assistance that allowed this study to take place: US Fish and Wildlife Service, Florida Sea Turtle Grants Program from the Sea Turtle License Plate, Florida Fish and Wildlife Conservation Commission, National Marine Fisheries Service, Norcross Foundation, East Coast Biologists, Save-A-Turtle Foundation, University of Central Florida Marine Turtle Research Group, Brevard Zoo, Maui Jim Sunglasses, Key West City Marina, M. K. Maxwell, and S. Gorham. We could not have conducted this study without our many volunteers who put in long hours and helped with every aspect of this project, including K. Holloway-Adkins, W. Bresette, L. Herren, S. Hirama, C. Koeppel, M. Koperski, S. Kubis, B. Lyon, K. Minch, R. Moretti, R. Scarpino, D. Witherington, and others too numerous to mention here. We thank C. Bell and an anonymous reviewer for their helpful comments on the manuscript. We dedicate this paper to the memory of our colleague Boyd Nathaniel Lyon.

\section{LITERATURE CITED}

Bjorndal KA (1980) Nutrition and grazing behavior of the green turtle Chelonia mydas. Mar Biol 56:147-154

Bjorndal KA (1985) Nutritional ecology of sea turtles. Copeia 1985:736-751

Bjorndal KA, Bolten AB, Chaloupka MY (2003) Survival probability estimates for immature green turtles Chelonia mydas in the Bahamas. Mar Ecol Prog Ser 252: 273-281

Bolten AB (2003) Variation in sea turtle life history patterns: neritic vs. oceanic developmental stages. In: Lutz PL, Musick JA, Wyneken J (eds) The biology of sea turtles. Vol II. CRC Marine Biology Series. CRC Press, Boca Raton, FL, p 243-257

Bresette MJ, Gorham J, Peery B (1998) Site fidelity of juvenile green turtles (Chelonia mydas) utilizing near shore reefs in St. Lucie County, Florida. Mar Turtle Newsl 82:5-7

Bresette MJ, Gorham J, Peery B (2000) Preliminary survey of sea turtles in the southern region of the Indian River Lagoon System. Fla Sci 63:43-44

Campbell CL, Lagueux CJ (2005) Survival probability estimates for large juvenile and adult green turtles (Chelonia mydas) exposed to an artisanal marine turtle fishery in the western Caribbean. Herpetologica 61:91-103

Clark PJ, Evans FC (1954) Distance to nearest neighbor as a measure of spatial relationship in populations. Ecology 35:445-453

Ehrhart LM (1985) Characterization of loggerhead and green turtle populations in the Indian River lagoon system, Florida, USA, with comments on use of the terms 'juvenile' and 'sub-adult.' Annual Joint Meeting of The American Society of Zoologists, The American Microscopical Society, The Animal Behavior Society, The Crustacean Society, The International Association of Astacology, and The Society of Systematic Zoology, Baltimore, MD. Am Zool 25:106A

Ehrhart LM, Ogren L (1999) Studies in foraging habitats: capturing and handling turtles. In: Eckert KL, Bjorndal KA, Abreu-Grobois FA, Donnelly M (eds) Research and management techniques for the conservation of sea turtles. IUCN/SSC Marine Turtle Specialist Group Publ. No. 4, p 61-64. Available from www.iucn-mtsg.org/ publications/
Ehrhart LM, Redfoot WE, Bagley DA (2007) Marine turtles of the central region of the Indian River Lagoon System, Florida. Fla Sci 70:415-434

> Hamilton WD (1971) Geometry for the selfish herd. J Theor Biol 31:295-311

Heithaus MR, Frid A, Wirsing AJ, Bejder L, Dill LM (2005) Biology of sea turtles under risk from tiger sharks at a foraging ground. Mar Ecol Prog Ser 288:285-294

Kildaw SD (1995) The effect of group size manipulations on the foraging behavior of black-tailed prairie dogs. Behav Ecol 6:353-358

Koch V, Brooks LB, Nichols WJ (2007) Population ecology of the green/black turtle (Chelonia mydas) in Bahia Magdalena, Mexico. Mar Biol 153:35-46

Krebs CJ (1989) Ecological methodology. Harper \& Row, New York

Linehan JE, Gregory RS, Schneider DC (2001) Predation risk of age-0 cod (Gadus) relative to depth and substrate in coastal waters. J Exp Mar Biol Ecol 263:25-44

> Makowski C, Seminoff JA, Salmon M (2006) Home range and habitat use of juvenile Atlantic green turtles (Chelonia mydas) on shallow reef habitats in Palm Beach, FL, USA. Mar Biol 148:1167-1179

Meylan PA, Davis K, Meylan AB (1994) Predicting sexual maturity of male green turtles from morphological data. In: Schroeder BA, Witherington BE (Compilers) Proc 13th Annu Symp Sea Turtle Biol Conserv. US Dept Commerce, NOAA Tech Memo NMFS-SEFSC-341:108

Meylan AB, Meylan PA, Gray-Conklin J (2000) Departure of marine turtles from developmental habitats: evidence from Bermuda and Panama. In: Kalb HJ, Wibbels T (Compilers) Proc 19th Annu Symp Sea Turtle Biol Conserv. US Dept Commerce, NOAA Tech Memo NMFS-SEFSC443:22

Moncada F, Abreu-Grobois FA, Muhlia-Melo A, Bell C and others (2006) Movement patterns of green turtles (Chelonia mydas) in Cuba and adjacent Caribbean waters inferred from flipper tag recaptures. J Herpetol 40:22-34

> Moran KL, Bjorndal KA (2007) Simulated green turtle grazing affects nutrient composition of the seagrass Thalassia testudinum. Mar Biol 150:1083-1092

Morrissey JF, Gruber SH (1993) Habitat selection by juvenile lemon sharks, Negaprion brevirostris. Environ Biol Fishes 38:311-319

> Morton TL, Haefner JW, Nugala V, Decino RD, Mendes L (1994) The selfish herd revisited: Do simple movement rules reduce relative predation risk? J Theor Biol 167:73-79

Pinder DA, Witherick ME (1975) A modification of nearestneighbor analysis for use in linear situations. Geography 60:16-23

Prins HHT, Ydenberg R, Drent R (1980) The interaction of brent geese Branta bernicla and sea plantain Plantago maritima during spring staging: field observations and experiments. Acta Bot Neerl 29:585-596

Pritchard CH, Bacon PR, Berry FH, Carr AF and others (1983) Manual of sea turtle research and conservation techniques. Western Atlantic Turtle Symposium, Center for Environmental Education, Washington, DC

Roos D, Pelletier D, Ciccione S, Taquet M, Hughes G (2005) Aerial and snorkeling census techniques for estimating green turtle abundance on foraging areas: a pilot study in Mayotte Island (Indian Ocean). Aquat Living Resour 18:193-198

Schmid JR (1998) Marine turtle populations on the west-central coast of Florida: results of tagging studies at the Cedar Keys, Florida, 1986-1995. Fish Bull 96:589-602 
Seminoff J, Jones TT, Resendiz A, Nichols WJ, Chaloupka MY (2003) Monitoring green turtles (Chelonia mydas) at a coastal foraging area in Baja California, Mexico: multiple indices describe population status. J Mar Biol Assoc UK 83:1355-1362

Troëng SD, Evans DR, Harrison E, Lagueux CJ (2005) Migration of green turtles Chelonia mydas from Tortuguero, Costa Rica. Mar Biol 148:435-447

Editorial responsibility: Jeffrey Seminoff, La Jolla, California, USA
Witherington B, Bresette M, Herren R 2006. Chelonia mydas - green turtle. In: Meylan P (ed) Biology and conservation of Florida turtles. Chelonian Research Monographs No. 3, Chelonian Research Foundation, Lunenburg, MA, p 90-104

Witzell WN (1987) Selective predation on large cheloniid sea turtles by tiger sharks (Galeocerdo cuvier). Jpn J Herpetol 12:22-29

Submitted: June 16, 2009; Accepted: October 9, 2009 Proofs received from author(s): December 21, 2009 